\title{
0 EDITOR'S CHOICE \\ Nursing in asylum seeker detention in Australia: care, rights and witnessing
}

\author{
D Zion, ${ }^{1}$ L Briskman, ${ }^{2}$ B Loff ${ }^{1}$
}

${ }^{1}$ Human Rights and Bioethics Unit, School of Public Health and Preventive Medicine, Monash University, 89 Commercial Road, Melbourne 3004, Victoria, Australia; ${ }^{2}$ Curtin University of Technology, Perth, Western Australia, Australia

\section{Correspondence to:}

Deborah Zion, Human Rights and Bioethics Unit, School of Public Health and Preventive Medicine,

Monash University, Australia; Deborah.zion@med.monash. edu.au

Received 14 February 2009 Revised 24 May 2009

Accepted 5 June 2009

\section{ABSTRACT}

The system of asylum seeker detention in Australia is one in which those seeking refuge are stripped of many of their rights, including the right to health. This presents serious ethical problems for healthcare providers working within this system. In this article we describe asylum seeker detention and analyse the role of nurses. We discuss how far an "ethics of care" and witnessing the suffering of asylum seekers can serve to improve their situation and improve ethical nursing practice.

\section{... the experience of suffering, it is often noted, is not effectively conveyed by statistics or graphs. (Paul Farmer)}

Even though Australia is a country founded upon both dispossession and forced migration, Australian governments appear to have learnt little. Australia's recent history of providing refuge for those exiled by violence and war is grim. Mandatory immigration detention for all those arriving in Australia without valid documents was introduced into legislation by the left-leaning Labor government in 1992. However, it was during the conservative government led by John Howard (1996-2007) that the mandatory detention of asylum seekers came to be used as a deterrent. As the then minister for immigration, Phillip Ruddock, asserted, the Government's asylum seeker policies had "been successful in deterring potential illegal immigrants from making their way to Australia". ${ }^{1}$

By 2001, almost 3000 people were held in asylum seeker detention while waiting for refugee protection determination, and some remained there for many years. Immigration Department figures reveal that the number of asylum seekers arriving by boat in the 2-year period prior to 1998 was 157 . In the year 2000 the number had increased to 4175 , causing alarm to the government and fear in the community. ${ }^{2}$ The government response escalated into increasingly severe measures, which received public support, particularly after the attacks in New York on 11 September 2001. Many people languished in detention for many years as they experienced the lengthy refugee determination process.

Detention facilities have operated in Melbourne, Sydney and Perth and in remote parts of Australia, such as Woomera and Port Augusta in South Australia and Port Hedland and Derby in Western Australia. However, for the most part, detention centres were situated in remote and inhospitable parts of the country. Detention camps also operated on Nauru and on Manus Island (Papua
New Guinea). These came to be known as the "Pacific solution", and there it became even more difficult for asylum seekers to access legal assistance in their claims for protection. Many seeking refuge came from Afghanistan, Iran and Iraq and had already experienced torture and trauma associated with war and oppression. Detention centres were contracted out to private prison companies, first Australasian Correctional Management and then Global Solutions Limited.

In remotely located centres, harsh physical conditions, isolation, hot weather, insects and reptiles contributed to the bleakness of the detainees' situation. Housing in some centres consisted of buildings of hollow concrete blocks, with asylum seekers sleeping in overcrowded huts with no air-conditioning. The asylum seekers were not guaranteed their own bed, or even a blanket. On some occasions, the first few weeks in detention were spent in a tent. ${ }^{3}$

More significantly for this study, immigration detention centres were isolated physically and legally from public scrutiny, as employees-including health professionals-were contractually bound to keep confidential any matter related to their work. As such, detention centres were worlds unto themselves when it came to the kind of accountability normally associated with, and relied upon in, daily healthcare practice, such as peer review and oversight by hospital and government administrative bodies. While doctors to whom asylum seekers were referred outside the detention setting experienced occasional ethical conflicts related to complicity with the detention system, nurses and psychologists who were directly employed by Australian Correctional Management and then by Global Solutions Limited under contract to the Department of Immigration had to find ways of managing the conflicted positions that came to dominate their working lives. Under this regime, nurses had little room to manoeuvre when it came to upholding the rights of asylum seekers, and in maintaining ethical practice in treating them. Healthcare practitioners often found themselves with "dual-loyalty" conflicts, in which their professional obligations to their patients diverged profoundly from their obligations to their employers.

In this article we focus on the role of nurses working with detained asylum seekers. In the first part of our discussion, we construct a picture of nursing in detention, using a structure developed by Guy Coffey. We describe the conditions of detention and examine ethical issues raised by the treatment setting, role conflicts and dual loyalties, and by the therapeutic relationship. ${ }^{4}$ In doing so, 
we draw upon published data and upon interviews undertaken by the authors with nurses who have worked in asylum seeker detention. We then discuss nursing ethics in relation to an "ethics of care", as formulated by theorists such as Carol Gilligan and Nel Noddings. Our purpose is to see how far this particular theory might assist in constructing ways in which ethical healthcare practice might be carried out. Finally, we look at how advocacy by asylum seeker nurses might restore and uphold rights of patients in this severely rights-deprived environment and the relationship - if any-this might have to the ethics of care already outlined.

Our discussion draws upon a conception of rights that is not reliant on the use of international human rights instruments alone, which depend upon a legal framework. Instead we utilise the work of writers such as Joseph Raz, who formulates a philosophy of rights as follows:

\footnotetext{
"X has a right" if and only if $\mathrm{X}$ can have rights, and other things being equal, an aspect of X's well-being (his interest) is a sufficient reason for holding some other person(s) to be under a duty. ${ }^{5}$
}

According to this formulation, we have a right to something when our interest in it is strong enough and important enough to confer a duty on another not to interfere with us in the performance of some action, or to secure us in something. "Basic rights", that is, rights to economic goods and political liberties that allow for a flourishing life, are generally accepted to be significant enough to confer such duties. ${ }^{6}$ In general, these duties are organised through state-controlled institutions. However, in asylum seeker detention, the protection of basic rights such as health were not ensured through any stategoverned organisation of duties.

We begin our analysis of asylum seeker nursing with the treatment setting.

\section{THE TREATMENT SETTING}

Healthcare in detention was chronically under-resourced both with respect to personnel and the means to provide treatment, as the provision of adequate healthcare would have imposed a significant cost to the prison companies contracted to manage detention centres. A former detention worker stated that Woomera's health centre was equipped to deal with eight to 10 detainees, but had to treat up to 40 (p 123). ${ }^{3}$ Further, high staff turnover undermined the possibility of therapeutic relationships emerging between staff and patients.

"Anne" worked for some time on the high risk assessment team, where patients were supposed to be assessed every shift. She recalls:

If you had 70 people for observation that means you had to see 70 people and you're meant to assess their mental state, their risk state ... and then you recommend whether they should remain on the level of observation they were on or whether that could be changed. It was impossible, of course, to see everyone every shift. First of all finding them let alone just seeing that number of people was absolutely impossible. (Interview with "Anne")

The physical conditions of healthcare in detention shocked many that arrived in places such as the Woomera and Baxter detention centres. In many detention centres, the clinics had barred windows, and there was constant noise from the public address system. " "Barry", who nursed in Woomera for several months, stated that it was difficult to maintain basic hygiene. Bandages were reused, the clinic floor was often muddy and babies' bottles were washed in the same sink in which urine was tested. Another nurse reports that during his first two stints at Woomera there was no sterilisation machine, and then when one arrived there were no instructions about how to use it.' (interview with "Barry").

The provision of treatment in itself often caused distress. Asylum seekers were identified by a code rather than by name. Many detainees were handcuffed during treatment. Asylum seekers who needed to receive medication had to stand for many hours in the hot sun in a queue and were then interviewed by a nurse in the presence of a guard.

"Anne", who nursed at Woomera, recalls:

Imagine being told by nursing colleagues that $\ldots$ anyone who wanted medication, for example, like if they had a headache had to come to the medical centre to get it. If they had indigestion and wanted Mylanta, had to come to the medical centre to get [it]. If they had back pain and wanted analgesic, they had to come to the medical centre and get it. Why shouldn't someone who is providing care go to that person and give them care? (Interview with "Anne")

Interpreters were also in short supply, and in many cases, when they were available they were a different gender from the patients. This further diminished the potential for communication and the development of a treatment relationship (interview with "Barry").

The role of guards in the detention setting created significant difficulty for the administration of treatment and severely undermined the professional autonomy of healthcare providers. Several nurses reported acts of brutality by guards towards detainees. Guards affected the treatment relationship by maintaining a menacing presence in the clinical setting when detainees were being treated. They often reported treatment decisions to management and questioned nurses in an intimidating way about their clinical decisions when off duty. ${ }^{7}$ Guards made decisions about who could attend the clinic, although they had no training in health. As "Barry" recalls,

I guess one of the biggest problems was that the guards decided that they would become the triage nurse, so they would determine who got through the gate and who didn't. So they'd ask what the problem was and if the person said "I've got a headache", well the guard would say that's not a good enough excuse to see the nurse. I had to ... say to some of the refugees, "If you want to get through the gate, tell them you've got chest pain, and they have a duty of care to let you through." (Interview with "Barry")

Patient notes were not routinely handed over from one shift to another. When a patient appeared in the clinic with a lifethreatening condition, especially during a night shift, the nurse might have had to give treatment without having access to the patient's medical history (interview with "Barry").

It is clear that the treatment setting-as part of the life of immigration detention - did little to redress of burden of illness caused or exacerbated by the detention. Instead the same problems that undermined health in detention were reinforced as detainees sought treatment.

\section{ROLE CONFLICT AND DUAL LOYALTIES}

When we talk about "dual loyalties", what do we mean? Recent scholarship on the subject states:

Dual-loyalty becomes especially problematic when the health professional acts to support the interests of the state or other 
entity instead of those of the individual in a manner that violates the human rights of the individual. The most insidious human rights violations stemming from dual-loyalty arise in health practice under a repressive government, where pervasive human rights abuses, combined with restrictions on freedom of expression, render it difficult both to resist state demands and to report abuses. In addition, closed institutions, such as jails, prisons, psychiatric facilities and the military, impose high demands for allegiance on health professionals even in the face of often-common human rights violations against individuals held there. But violations of human rights at the behest of the state by health professionals also take place in open societies. ${ }^{8}$

Nurses were "the front line and the heart of health care in detention centres".? Furthermore, the health services manager, normally a nurse, was responsible for healthcare in each detention centre. As such, nurses-or some nurses-had great power in the detention setting. However, their power was limited to enforcing the rules set out by the private detention providers and the Department of Immigration, even if these went against the best interests of patients. When working in the detention setting, nurses were unable to insist upon the usual professional standards and norms and to deliver healthcare ethically. There are many reports of nurses who, when they tried to do so and disobeyed the instructions issued by either Australasian Correctional Management or the Department of Immigration, were threatened and abused (interview with "Barry"). ' Hence their role was fraught with dual-loyalty conflict. More fundamentally, patients were also cognisant of the dual-loyalty conflict in which nurses were caught, which contributed to mistrust between patient and care provider.

Several nurses reported that they felt working in detention in itself presented a role conflict-namely, that they had a professional duty to care for detainees, but were also employed as part of an organisation and in a process that undermined good healthcare and was in itself making their patients sick. As Glenda Koutroulis stated,

\begin{abstract}
As I look back on my time in Woomera Detention Centre, picturing the silver fences and razor wire that mark it, entrapping all those whose implacable despair will burden Australia long after I am gone from this earth, I think about what I was involved in. It was unequivocally observation of and participation in something very indecent ... As I reflect, angry and ashamed with what I have witnessed and experienced I feel like I was unknowingly part of a perverse social experience, testing endurance in the face of deception and incongruous decisions about freedom, and the capacity to survive in those who have already struggled to survive. ${ }^{9}$
\end{abstract}

Koutroulis' statement gives us a strong sense of what is entailed in dual-loyalty conflict. It is not, therefore, surprising that issues related to dual loyalties were common in the daily life of healthcare providers in detention. In what follows we will describe three examples of dual-loyalty conflict and discuss their significance in terms of nursing ethics.

Our first example concerns Michael Hall, who was a nurse at Curtin in northern Western Australia and later on Christmas Island. He finally left detention nursing when he was asked to accompany two pregnant women to the mainland for delivery. Hall stated that he felt that accompanying the women and being involved in their separation from their families went against his professional and ethical duties. He stated, "[To] have to follow the instructions of a politician is grossly negligent and could even be construed as abuse."

In the second example, nurses were involved in the use of "chemical restraints", thereby acting as an arm of the prison establishment. ${ }^{11}$ Asylum seekers whose claim for refugee status had been refused were sometimes sedated through injection before being forcibly removed from Australia. One former asylum seeker recalls:

I heard my name on the speaker, and I was escorted to meet the immigration officers. I said let me talk to my lawyer and they said no. They locked me in the isolation place. I was feeling very scared. Then I start to harm my hand. If my hand is injured they will take me to clinic. If they take me to clinic the other detainees will see me, they will ring my lawyer.

Then I found maybe 16, 17 officers around me. They hold my legs together and they bend the big belt and kicked my chin and bound my hands together. They stood over my body and the nurse has an injection and Valium tablets. I said I don't want an injection. I don't want tablets. They tried to do it maybe twenty minutes. I was very angry, screaming and they couldn't. My muscle was very tight because I was frightened. And then they forced me. ${ }^{3}$

The third example involves the way in which nurses were frequently the conduit through which asylum seekers found themselves in solitary confinement. In many detention centres these cells were also used for "behaviour modification". The 2005 Amnesty International Report stated that

There have been reports of detainees being held in the MSU or medium-security Red 1 compounds for weeks, even months, at a time for anything from spitting at an employee, refusing to obey an instruction or inflicting self-harm. ${ }^{12}$

Patients who were at risk of self-harm were often isolated in small, brightly lit cells with no privacy. A diagnosis of risk therefore carried with it the danger of making the patient's situation worse.

In all of these examples, the nurses involved were faced with dilemmas that exemplify what Stephen de Wijze refers to as the "problem of dirty hands", whereby a person who is trying to behave ethically has to choose between the lesser of two evils because of the unethical acts of others. ${ }^{13}$ In the first case, Hall had to choose between providing care and supporting a system that he believed to be harmful and unjust. In the second case, nurses had to choose between injecting patients themselvescontributing to the human rights violations that might include refoulment-or have one of the guards use other forms of violence to restrain detainees. In the third case, nurses had to determine whether or not the risk of self-harm outweighed the abuse of solitary confinement, with few or no alternatives and available effective treatments.

\section{THE TREATMENT RELATIONSHIP}

Nursing involves intimate and ongoing contact with patients. Many who write about nursing discuss the ways in which this intimate treatment relationship is the cornerstone of practice. Here the security regime that determined the daily life of people in detention inhibited nurses from developing therapeutic relationships with detainees. The treatment relationship between detainee and nurse was highly compromised. It did, however, offer a site of resistance for nurses to attempt to improve the conditions of asylum seekers.

As discussed above, the role of guards was highly significant in shaping the provision of healthcare in detention. Mark Huxtep, who nursed in Woomera, gives a clear picture of guards' attitudes to detainees, which shows us how harmful 
their presence would have been to the treatment relationship between nurses and their patients:

\begin{abstract}
. almost every time a guard opened their mouth to speak to a detainee or to speak about a detainee, they would use derogatory remarks toward them, including the women and children. This included using words like "scum, wog/s, cunt, little cunt, slut, trash, vermin, asshole/s, boaties, rezzies". Not every guard spoke this way about the detainees, but many did, and this included speaking to them like this to their face and also in front of them as if they didn't exist (in the 3rd person).
\end{abstract}

Nonetheless, it was within the treatment relationship where nurses seemed most able to redress some of the horrors of detention. Doing so involved devising ways in which nurses could interact with detainees without guards being present. Despite a rule of separation between staff and detainees, several nurses reported visiting detainees to administer medicine, or to introduce new nurses to detainees, or simply to talk to them in order to "validate that their situation was really as grim as it was" without guards being present. Others arranged for supporters outside detention to send in health- and lifepreserving items such as proper shoes for diabetics and clothes for small children and babies (interview with "Susan").

Treating detainees with kindness and respect and seeking even small ways to ameliorate both their physical and mental suffering was in itself an act of resistance by those nursing in detention. Mark Huxtep reported requesting that additional milk and fruit be given to children. When this was not forthcoming, he and other nurses provided detainees with their own supplies. In such instances, guards would report nurses for "crossing the line". On other occasions, guards would follow nurses home from the detention centres, listen to their conversations and report them (interview with "Barry").

Commonly accepted ethical benchmarks such as patient confidentiality were lacking in the detention setting. Michael Hall, another detention nurse, reported that trying to maintain any ethical standards, such as patient confidentiality, carried with it dangers to the healthcare professional concerned. When Hall refused to hand over confidential medical records without the consent of the patient, the following ensued:

Soon the inevitable request for a medical health record came to which I requested DIMIA [Department of Immigration] provide evidence of the detainee giving permission. In full view of ACM [Australasian Correctional Management] and DIMIA staff, as well as detainees, this career immigration official yelled abuse at me, threatened to have me permanently removed from the premises and then, while physically threatening me, he proceeded to remove medical health records from the clinic. ${ }^{10}$

So far, we have discussed some of the issues that beset the delivery of nursing care in asylum seeker detention. In what follows, we explore whether or not current debates concerning nursing ethics can assist in formulating ways in which healthcare might be delivered with integrity and rights might be restored and maintained within this population. We will test how far an "ethics of care" has the capacity to restore autonomy and rights to patients existing in a situation of extreme rights deprivation, or whether those nurses who demonstrated behaviour congruent with such an ethic were able, through their practice, to at least restore dignity and hope when rights were not being upheld through the structures of detention. We will then question what other means might be available for nurses to practice healthcare ethically and to uphold the rights of this population.

\section{NURSING ETHICS}

There is a considerable body of literature concerning nursing ethics. As Joan McCarthy states,

"Nursing ethics" does not describe a single academic discipline or subject area. Rather, it is best understood as an umbrella term for a number of different related areas of inquiry. ${ }^{14}$

In her discussion of the relationship between ethical theory and nursing practice, McCarthy identifies two views of nursing ethics. The first of these draws upon the work of writers such as Søren Holm, who believe that nursing ethics is not significantly different from other branches of healthcare ethics. Holm suggests that the core issues relating to nursing and medicine, such as confidentiality, autonomy and consent, are the same, as are the ways in which doctors and nurses identify and work through ethical problems. ${ }^{14} 15$

There are many who dispute the kind of view put forward by Holm. Writers such as Sara Fry and Janet Storch suggest that nursing ethics starts and develops from the basis of the nurse/ patient relationship. ${ }^{14} 1617$ Others, such as Peter and Liaschenko, ${ }^{18}$ follow on from the work of Margaret Urban Walker and further refine these ideas. They suggest that responsibility within this relationship is the core of a nursing ethical framework. They state:

The work of nursing is obviously constituted by practices of responsibility for those who are sick, injured, or in need of other health care measures. To the extent that patients are vulnerable as a result of disease and injury, they are even more so because, regardless of the severity of disease or injury, all who need our services are vulnerable to our actions and choices. Nurses are the so-called "glue" of the health care system because they are socially located as boundary workers. ${ }^{18}$

The emphasis on the nurse/patient relationship, in which the healthcare practitioner is directly involved with the suffering and intimate care of the patient, lends itself particularly well to feminist ethics or an "ethics of care", where the context of care provides the background of ethical decision-making, rather than a set of principles or theories against which ethical decisions are measured. In what follows, we will describe the ethics of care and show how it relates to the experiences of nursing in asylum seeker detention.

\section{AN "ETHICS OF CARE"}

The body of work that is often referred to as an "ethics of care" was developed in response to a perception that the centrality of autonomy as separateness in ethical theory was irrelevant to lived experience. Following the work of Carol Gilligan, ${ }^{19}$ writers such as Nel Noddings privileged characteristics such as caring, responsibilities and relationships over justice and rights. ${ }^{20}{ }^{21}$ As Carol Quinn states, "Care based morality is grounded in empathy towards others ... It refers to a particular orientation towards others, in which we care not so much about others' abstract rights as about their concrete needs." 22

MacDonald states:

An ethics of care therefore has at its core the idea that "individual autonomy is socially dependent: that is, the capacity and opportunity for autonomous action is dependent on our particular social relationships and the power structures in which we are embedded. ${ }^{23}$

Nursing ethics that embraces this model of relational care supports the idea that the achievement of autonomy is enabled 
through the "support and guidance of emotionally engaged others". 24

How might this ethical theory relate to nursing in asylum seeker detention? It is clear that actions congruent with an ethics of care could not compensate for the inhuman conditions in which asylum seekers found themselves. Such changes required political action. Nonetheless, in trying to provide care against considerable odds, many nurses interviewed in our study still managed to focus on a nursing practice in which the responsibility for the patient's well-being and the development of relationships were central, although perhaps not based upon any conscious ethical viewpoint. On what Benatar, Daar and Singer describe as the micro level, these face-to-face interactions might have helped to restore hope and to draw asylum seekers back into the human circle, as well as providing basic goods such as food and appropriate treatment. ${ }^{25}$ It is doubtful, however, that the acts of caring promoted autonomy or the ability of detainees to control any significant aspect of their lives, for to think of autonomy in a situation of such profound rights deprivation underplays the connection between autonomy and freedom.

Many writers have suggested that autonomy is a state dependent upon a person's mental competence. Others, however, have argued that one cannot be the author of one's own life course without enjoying what Henry Shue refers to as "basic rights". ${ }^{6}$ According to Shue, basic rights are not more important than other rights, but they are necessary conditions of them. Therefore, in order to enjoy the right to education, we must first have obtained enough food to be able to go to school. Underpinning Shue's conception of basic rights is the idea that a self-directed life must be based upon having adequate choices.

This view is upheld by Joseph Raz, who tells two stories about how material and political circumstances determine choice, and how choice, in turn, is a fundamental part of leading an autonomous life. The first of these stories concerns a "Man in a Pit", whose choices are limited to "whether to eat now or a little later, whether to sleep now, or a little later, whether to scratch his left ear or not". His second example concerns a "Hounded Woman", who spends her whole life on a desert island, trying to escape a carnivorous creature that is trying to devour her. Raz suggests that while both of these subjects have choices, they cannot be called autonomous, for "... one has only trivial options to choose from ... The other person's predicament is the opposite one. All her choices are potentially horrendous in their consequences." ${ }^{\prime \prime}$

Raz's understanding of choice and autonomy is in stark contrast to the idea that autonomy is a mental process by which we can always choose our response to the world around us, and that this is a sufficient condition for autonomy. Instead, he sees having sufficient options to be a state that exists above a baseline of necessity for a meaningful expression of autonomy that relates to a life plan.

The acts described by nurses in this discussion failed to restore autonomy to asylum seekers in their care. Their actions instead provided some degree of hope and drew asylum seekers back into the human circle. If asylum seekers had been able to access and enjoy their rights, the acts we have described that are congruent with an ethics of care would have been different in nature and have served a different purpose. For example, the provision of basic necessities such as food and medicine would have been assured, and the fostering of relationships between nurses and patients would have assisted patients in reaching autonomous decisions about treatment options. Nothing could be further from the realities of the detention setting.
Some nurses in our study, however, moved beyond care in an effort to restore rights to asylum seekers. To do so, however, they had to move outside the clinical setting.

\section{RESTORING RIGHTS IN DETENTION: THE SIGNIFICANCE OF WITNESSING}

We have discussed the way in which those who came seeking refuge and ended up in asylum seeker detention centres were stripped of many of their rights, including the right to health. Given the limits already described on care providing a means through which patient autonomy and freedom might be enhanced, what could nurses (and other healthcare providers) do?

Apart from providing care, in many cases nurses who worked with asylum seekers acted as witnesses to their suffering. The significance of witnessing is two-fold. As David Robertson and colleagues state,

First it entails being with people who are victims of injustice or violence and thereby showing that they have not been abandoned. Second, it entails testifying to the outside world about the injustice or violence observed, and advocating that the world community bring about change. Bearing witness can thus facilitate and fuel human solidarity in the face of tragedy, and contribute to focussing international attention. ${ }^{26}$

Many nurses have spoken up regarding conditions in detention to government inquiries - to the People's Inquiry led by the Australian heads of social work, ${ }^{3}$ to the press and to researchers such as ourselves. By doing so they have managed to break down some of the secrecy that surrounded the conditions of asylum seeker detention and have caused the Australian public and those involved in policy and legislation to begin to change the living conditions of those seeking asylum in Australia. The descriptions of daily life in detention and the suffering it has caused, as well as the reasons that these people have risked the journey to Australia, have provided a means through which some of the stigmatisation of asylum seekers has been broken down. Given the intimate knowledge nurses had about daily life in detention, they were particularly well placed to reveal the daily conditions of asylum seekers. As Natalie Grove and Anthony Zwi have stated, "Maintaining the "otherness" of refugees and asylum seekers, requires that they and their stories remain distant and strange, that we rarely hear from them or come to know them." ${ }^{\prime 27}$

\section{CONCLUSIONS}

Zachary Steel and colleagues have outlined the way in which immigration law superseded health law, and child protection turned detention prisons into an ethical no-persons' land.

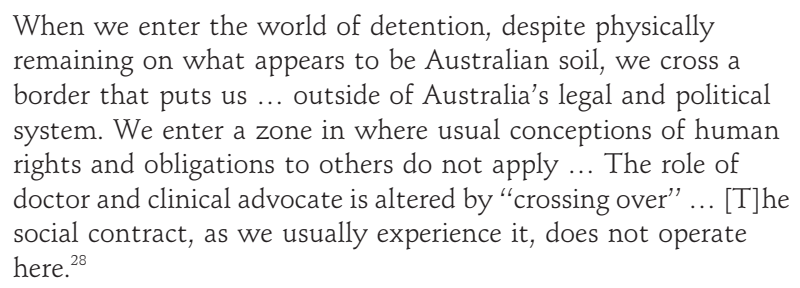
border that puts us ... outside of Australia's legal and political system. We enter a zone in where usual conceptions of human rights and obligations to others do not apply ... The role of doctor and clinical advocate is altered by "crossing over" ... [T] he social contract, as we usually experience it, does not operate here. $^{28}$

Our discussion of nursing in the detention setting has shown how problematic it was to deliver healthcare ethically without the structures that usually protect and enhance the right to health. It is clear, however, that many nurses who worked in places such as Woomera and Baxter went out of their way to improve the health of their patients day-to-day basis, and 
ensured, often at some personal cost, that their stories of neglect and abuse were put on the public record.

Funding: The project has been funded by the Australian Research Council.

Competing interests: None.

Provenance and peer review: Not commissioned; externally peer reviewed.

\section{REFERENCES}

1. Ruddock P. Immigration: border protection. Parliament of Australia, Hansard. 2002: p420. (House of Representatives, Questions without notice.) http://parlinfo.aph.gov. au/parllnfo/search/display/display.w3p;adv $=; \mathrm{db}=;$ group $=;$ holdingType $=; \mathrm{id}=$ ;orderBy =; page = 0; query = Id\%3A\%22chamber\%2Fhansardr\%2F2002-02-

19\%2F0013\%22:querytype $=; r e c=0 ;$ resCount $=$ Default (accessed 25 Jul 2009).

2. Bem K, Field N, Maclellan N, et al. A price too high: the cost of Australia's approach to asylum. Glebe, New South Wales: A Just Australia, and Carlton, Victoria: Oxfam Australia, 2007:13.

3. Briskman L, Latham S, Goddard C. Human rights overboard. Melbourne: Scribe Publications, 2008:115-20.

4. Coffey G. "Locked up without guilt or sin." The ethics of mental health service delivery in immigration detention. Psychiatry, Psychology and Law 2006;13:67-90.

5. Raz J. The morality of freedom. Oxford: Clarendon Press, 1986:166.

6. Shue H. Basic rights: subsistence, affluence and U.S. foreign policy. Princeton: Princeton University Press, 1980.

7. Australian Human Rights and Equal Opportunity Commission. A last resort? (Report of the National Inquiry into Children in Immigration Detention.) 2004. http:// www.humanrights.gov.au/human rights/children detention report/index.html (accessed 25 Jul 2009)

8. Physicians for Human Rights (PHR). Dual loyalty and human rights in health professional practice: proposed guidelines and institutional mechanisms. Cambridge, MA: PHR, 2003. http://physiciansforhumanrights.org/library/report-dualloyalty-2006. html (accessed 4 Jul 2009).

9. Koutroulis G. Detained asylum seekers, health care, and questions of human(e)ness. Aust N Z J Public Health 2003;27:4, 381-84, p384.

10. Hall M. The rules: nursing in a detention centre. 2002. http://www.safecom.org.au/ michael-hall.htm (accessed 4 Jul 2009)

11. 3CR Community Radio. The use of chemical restraint in deportations [interview] Victoria: Refugee Action Collective (Victoria), 2003. http://www.rac-vic.org/html/ chem-res.htm (accessed 4 Jul 2009). (Transcript of interview of Barbara Rogalla and Charandev Singh.)

12. Amnesty International. Australia: the impact of indefinite detention: the case to change Australia's mandatory detention regime. 2005. http://www.amnesty.org/en/ library/info/ASA12/001/2005 (accessed 4 July 2009).

13. de Wijze S. Defining evil: insights from the problem of "dirty hands". Monist 2002;85:210-39.

14. McCarthy J. A pluralist view of nursing ethics. Nurs Philos 2006;7:157-64, 158.

15. Holm S. Ethical problems in clinical practice. Manchester: Manchester University Press, 1997:197-203

16. Fry S. Toward a theory of nursing ethics. ANS Adv Nurs Sci 1989:11:9-22.

17. Storch JL. Nursing ethics: a developing moral terrain. In: Toward a moral horizon. Storch JL, Rodney P, Starzomski R, eds. Toronto: Pearson Education Canada, 2004:1-16.

18. Peter E, Liaschenko J. Whose morality is it anyway? Thoughts on the work of Margaret Urban Walker. Nurs Philos 2003:4:259-62.

19. Gilligan C. In a different voice: psychological theory and women's development. Harvard: Harvard University Press, 1993.

20. Noddings N. Caring: a feminine approach to ethics and moral education. Berkeley: University of California Press, 2003

21. Donchin A. Integrating bioethics and human rights: toward a global feminist approach In: Tong R, Donchin A, Dodds S, eds. Linking visions. feminist bioethics, human rights and the developing world. Boulder: Rowman and Littlefield Publishers, 2004:31-56.

22. Quinn C. On learning how to care appropriately: a case for developing a model of support for those in need. In: Tong R, Donchin A, Dodds S, eds. Linking visions: feminist bioethics, human rights and the developing world. Boulder: Rowman and Littlefield Publishers, 2004:105-18.

23. MacDonald C. Relational professional autonomy. Camb 0 Healthc Ethics 2002;11:282-9.

24. Bowden P. An "ethic of care" in clinical settings: encompassing "feminine" and "feminist" perspectives. Nurs Philos 2000;1:36-49.

25. Benatar SR, Daar AS, Singer PA. Global health ethics: a rationale for mutual caring Int Aff 2003:79:107-38.

26. Robertson D, Bedell J, Lavery J, et al. What kind of evidence do we need to justify humanitarian medical aid? Lancet 2002;360:330-3

27. Grove N, Zwi A. Our health and theirs: forced migration, othering, and public health Soc Sci Med 2006;62:1931-42.

28. Steel Z, Mares S, Newman L, et al. The politics of asylum and immigration detention: Advocacy, ethics and the professional role of the therapist. In: Wilson JP, Drozdek B eds. Broken spirits: the treatment of traumatized refugees, war and torture victims. New York: Brunner Routledge, 2004:659-89. 